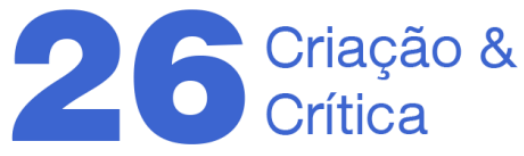

\section{A TRANSFIGURAÇÃO DO DRAGÃO OU A SOBREVIDA DO REGIONALISMO}

\author{
Maryllu de Oliveira Caixeta ${ }^{1}$
}

RESUmO: No conto de Tutaméia "Reminisção", Romão demonstra amor incondicional por sua mulher. No final, ela transfigura-se abraçada ao marido que "morre". O conto oferece uma alegoria parodística da função de Rosa, o autor que supera a sobredeterminação da literatura brasileira ao regionalismo e às cópias falsas de modas estrangeiras. $O$ índice de Tutaméia assinala alguns contos que metaforizam o ponto de vista de João Guimarães Rosa sobre a ordem da qual participa, intervindo nela. Parece-me que o conto "Reminisção" oferece o ponto de vista de Rosa a respeito da função de seu nome de autor regional-universal, na evolução da história da literatura brasileira. Para estudar o modo como essa função se constituiu, considero a contribuição decisiva de Antonio Candido, a partir da estreia do ficcionista nos anos de 1940 e também no ensaio dos anos de 1970 que o consagra escritor super-regionalista latino-americano. Para analisar "Reminisção", como alegoria parodística da função de autor regional-universal, separo o conto em três partes, correspondentes a três fases de evolução da história do regionalismo; depois, analiso o modo como o vocabulário exótico do conto contribui para a indeterminação de seu sentido, e proporciona ao leitor a materialidade dos contornos da metafísica da superação, pressuposta na função transfiguradora parodiada.

PALAVRAS-CHAVE: Guimarães Rosa, Tutaméia,"Reminisção”,transfiguração,regional-universal.

\section{TRANSFIGURATION OF THE DRAGON OR SURVIVAL OF REGIONALISM}

ABSTRACT: In a story by Tutaméia, "Reminisção", Romão shows an unconditional love for his wife. In the end, she is transfigured hugging her husband who "dies". The story offers a parody allegory of the role of Rosa, the author who overcomes the overdetermination of Brazilian literature to regionalism and to and false copies of foreign trends. The Tutaméia index indicates some stories that metaphor the point of view of João Guimarães Rosa on the order in which he participates and intervenes. It seems to me that the story "Reministion" offers Rosa's point of view on the role of his regionaluniversal author's name in the evolution of the history of Brazilian literature. To study how this function was constituted, I consider Candido's decisive contribution since the launch of the fictionist's first book in the 1940s and also an essay from the 1970s that attributed to Rosa the epithet of the Latin American super-regionalist writer. To analyze "Reministion" as a parody allegory of the regionaluniversal author function, I separate the story into three parts corresponding to three stages of evolution in the history of regionalism. Then I analyze how the exotic vocabulary of the story contributes to the indeterminacy of its meaning and provides the reader with the materiality of the metaphysics of overcoming's contours, inside the parodied transfigurative function.

KEYWORDS: Guimarães Rosa, Tutaméia, "Reminisção", transfiguration, regional-universal.

${ }^{1}$ Doutora em Estudos Literários pela Universidade Estadual Julio de Mesquita Filho. Desenvolveu uma pesquisa de pós-doutorado na Universidade de São Paulo, a propósito da função do nome de João Guimarães Rosa em Tutaméia: terceiras estórias. 


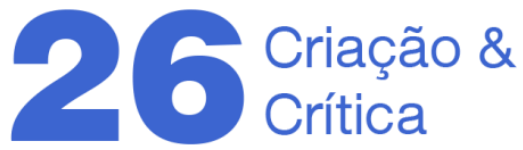

Parece-me que a primeira recepção de Tutaméia: terceiras estórias não foi muito entusiasmada. Levo em consideração que o lançamento do livro havia sido feito pouco antes da morte de João Guimarães Rosa. O autor já ocupava, em 1967, uma posição de enorme destaque na história da literatura brasileira, tendo inclusive entrado para a Academia Brasileira de Letras três dias antes de sua morte. Até houve uma bibliografia considerável de crítica a respeito do livro, com ensaios e artigos mais ou menos breves, alguns deles assinados por críticos que, vez por outra, manifestaram algum incômodo, admoestação ao autor ou mesmo certa desaprovação. Alguns anos depois de seu lançamento em 1967, houve uma publicação mais ou menos extensa sobre Tutaméia, acrescentada como anexo ao estudo O insólito em Guimarães Rosa e Borges (1978), que resultou da dissertação de mestrado de Lenira Marques Covizzi, defendida em 1970, sob orientação de Antonio Candido. Covizzi considerou o livro de contos um excesso, dispensável em relação ao conjunto da obra de Rosa, por ter repetido resultados já alcançados em livros anteriores e melhor desenvolvidos neles. Apenas no final da década de 1980, o pé atrás da crítica com o livro começou a ceder a uma postura mais receptiva, quando Vera Novis, em seu ensaio Tutaméia: engenho e arte, considerou desafiador o humor do livro, associando-o a suas novidades de estruturação, de pesquisa de material. De lá pra cá, vêm surgindo muitos estudos sobre o livro, especialmente pesquisas de pós-graduação, como a que fiz. Em minhas tentativas de pensar o que pareceu a Vera Novis uma reação meio embaraçada da primeira crítica, tenho levantado a hipótese de que Rosa ironiza, esvazia, modelos clássicos e padrões de representação realista ${ }^{2}$, o que agrupa sua literatura à de autores do século XIX e do XX sensíveis à crise moderna da ficção e do autor. Essa posição se confere no estilo de Rosa, que porta marcas avaliativas desses padrões, e confrontando-as tenho pensado, desde minha pesquisa de pós-doutorado, a função que seu nome de autor assumiu na história da literatura brasileira.

Todos sabemos que Rosa tem posição de destaque na história da literatura brasileira porque, nela, assume a função de autor regional e universal, que oferece um modelo de superação, de transfiguração do regionalismo, mostrando-se superior também à tendência de se imitar mal os estrangeiros, sem apropriação suficiente das questões estético-políticas da época. Consideremos a contribuição de Antonio Candido no estabelecimento dessa função, pois me parece que teve impacto decisivo naquilo que avalio como um certo embaraço da primeira crítica de Tutaméia, aquela anterior ao livro de crítica publicado por Vera Novis em 1989. A reação pouco eloqüente da primeira crítica, quando não

\footnotetext{
${ }^{2}$ Em O O, a ficção da literatura em Grande sertão - veredas (2000), e em alguns ensaios posteriores, João Adolfo Hansen tem considerado os modos como Guimarães Rosa recusa os modelos clássicos e os padrões de representação realista.
} 


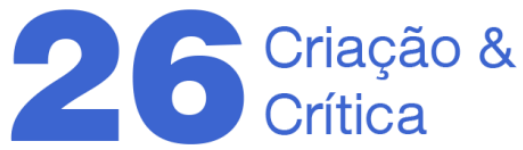

decepcionada, chama a minha atenção porque não a interpreto como sinal de desinteresse, mas como um constrangimento provocado pelo fato de o livro parodiar, com insistência, concepções fundamentais na canonização de Rosa. Tenho estudado Tutaméia, considerando-o uma recusa enfática de modelos clássicos e de padrões realistas de representação, enquanto a crítica de Rosa quase sempre tende a se afinar com Candido, que toma esses modelos e esses padrões como tendências assimiladas e transfiguradas no realismo superior, regional-universal e super-regionalista, de Rosa. Quase toda a crítica afirma que Rosa é autor de um realismo regional-universal, concordando com a avaliação de Candido e, às vezes, extrapolando-a, a ponto de negar qualquer valor regional na representação, por considerar o regional transfigurado nessa literatura. Outras vezes, a crítica ainda examina a autenticidade da transfiguração atribuída por Candido a Rosa a partir de um juízo de gosto particular, datado e historicamente produzido ${ }^{3}$, embora quase sempre considerado claro, transparente e universal/essencial. Venho estudando Rosa como autor moderno que recusa a transparência da metafísica da transfiguração que o canonizou como autor de um realismo regional-universal; e essa recusa não é nada discreta em Tutaméia, o que tornou o livro embaraçoso. Mas antes de pensar o impacto indireto, silencioso, de Candido no embaraço da primeira recepção de Tutaméia, convém lembrar o impacto direto desse pensamento na canonização de Rosa, a partir de sua estreia em 1946, tendo contribuído decisivamente para sua consagração, ao considerá-lo autor de um realismo regional-universal que, ao transfigurar o regionalismo em uma forma total, transcendental, torna-a modelo político e estético de superação.

\section{Machado e Rosa: dois pontos decisivos na transfiguração das constrições aos modelos estrangeiros e ao regionalismo, para além da "morte"}

Para os fins desse ensaio, farei observações muito gerais sobre a obra de Candido, especialmente quando tem por objeto Rosa e o regionalismo, atentando para o fato dessa tendência ter proliferado no mesmo período em que Machado de Assis participou de modo incisivo na crise moderna da ficção. Não me estenderei na demonstração do que afirmo, porque são coisas muito conhecidas e porque disponho apenas ângulos úteis à explicação daquilo que, segundo me parece, se tornou objeto de paródia, no conto "Reminisção".

\footnotetext{
${ }^{3}$ A respeito da historicidade dos juízos aplicados por Candido, em alguns de seus ensaios mais conhecidos, conferir o livro de Anita Martins Rodrigues de Moraes (2015), intitulado Para além das palavras: representação e realidade em Antonio Candido.
} 


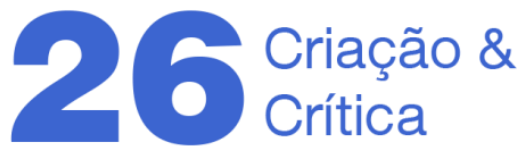

Tendo sido um crítico modernista importante na canonização de Rosa desde sua estreia em 1946, Candido, no ensaio "O homem dos avessos" fato de o ficcionista ter superado a tendência da literatura brasileira a um tipo de realismo que se detém no documento bruto. Rosa foi romancista de um realismo superior ${ }^{5}$, superregionalista conforme conceito usado por Candido em outro ensaio. Se, nos manuais, aprendemos que Machado é um autor realista do século XIX, restando discutir o grau de plausibilidade de sua ficção, com Candido aprendemos que o tipo singular de realismo (em sentido lato) de Machado superou a moda realista de sua época, aquela ao modo de Eça de Queirós. Rosa também se lê nessa chave ou, pelo menos, como um autor vinculado à tradição de se representarem as regiões usando-se a convenção realista, da qual portanto deriva, conforme Candido, mas superando-a pela transfiguração desse regional em universal.

Candido escreveu a história do regionalismo, conduzindo-a a dois pontos de efetivação de um realismo superior, aquele que transfigura totalmente coisas brutas em outras, universais. Primeiro Machado no final do século XIX, depois Rosa que, nos anos de 1940, estava a par do desejo generalizado de universal, de superação do passado, saliente entre escritores modernistas, e em discussão polêmica no final da década de 1930.

Como se sabe, conforme o Formação da literatura brasileira: momentos decisivos ${ }^{6}$, escrito por Candido de 1945 a 1957 e publicado em 1959, a história da literatura brasileira, cujas constrições remontam às fases de formação, é atravessada por um sentido de missão que, até aquela década de 1940, havia feito os escritores experimentarem uma tensão dialética entre coisas particulares, fossem regionais ou nacionais, e outras gerais/dominantes, como a norma culta, as temáticas urbanas, as tendências estéticas universais. O cuidado quanto a uma posição equilibrada ante essa tensão gerou autores centrais e decisivos como Machado e Rosa, mais ou menos ilhados da tendência, da literatura brasileira empenhada, ao realismo de observação direta das coisas brutas, e distintos também de modas estrangeiras intermitentes, superficialmente assimiladas. $\mathrm{Na}$ apreciação de Candido, a ficção universalizante de Machado pertenceu à tendência da literatura brasileira aos temas urbanos e ultrapassou a moda estrangeira do realismo à Eça de Queirós cujo famoso romance o próprio Machado (s./d., p.165) chamou de "reprodução fotográfica e servil das coisas mínimas e ignóbeis" ou "exação de inventário" no tratamento do escuso e do torpe, em seu texto de crítica dedicado a "O Primo Basílio". Simultaneamente à tendência das temáticas urbanas, no século XIX, também surgiu a do regionalismo, superado por Rosa de modo decisivo, por ter aproveitado o que tinha de melhor, rejeitando

\footnotetext{
${ }^{4}$ Falo do ensaio "O sertão e o mundo" [1957], republicado em Tese e antítese como "O homem dos avessos".

${ }^{5}$ A esse respeito, foi muito esclarecedora a comunicação que Lúcia Ricotta Vilela Pinto apresentou na ABRALIC de 2019, intitulada "O mundo de Grande sertão: veredas vai deixando de ser candidiano".

${ }^{6}$ A partir de agora, começo a me referir a esse livro como o Formação.
} 


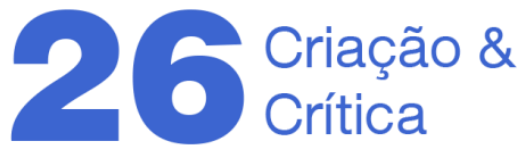

defeitos, já apontados por Machado no "Instinto de Nacionalidade", relativos a excessos de descrição, de atenção a coisas mínimas, brutas, sem transcendência maior que o inventário do exotismo do outro cultural: camponeses, provincianos, rudes, primitivos, marginalizados, (a)normalizações que constituem o outro das normas de civilidade.

Machado e Rosa figuram, na história da literatura brasileira, como exceções à tendência dela de pender mais para o lado da atenção às coisas brutas, em processo de elaboração pelos intelectuais desde a Independência em 1822. Tais coisas foram sistematicamente definidas, em suas formas nacionais, apenas nos anos de 1930, dentro de histórias de formação propostas em ensaios clássicos de interpretação, constitutivos das matérias Brasileiras como tal. Da perspectiva desse projeto romântico de formação gradativa do nacional, sua indefinição perdurou por um longo período de condições desfavoráveis à contribuição sistemática dos intelectuais, dos artistas, o que acabou revertendo-se a partir dos anos de 1930, com a contribuição das forças históricas da unificação política. Pressupondo a persistência da indefinição das coisas brutas nacionais, ante as quais os escritores precisaram fazer enormes esforços de observação direta, Candido afirma a tendência estrutural da literatura brasileira ao realismo documental, ao que acabou conferindo maior visibilidade por atenção ao que defendeu ser a principal constrição, limitação e condição de superação, à conquista de autonomia estética e política. Do outro lado dessa tensão dialética, para além do risco de se deixarem absorver pela escuridão das coisas brutas, os escritores brasileiros ainda precisam resistir à sedução do artifício importado das literaturas dos grandes centros mundiais de produção cultural. Esse artifício, mal digerido, destaca-se na literatura de temática urbana, nos sintomas do narcisismo burguês, no intimismo de lastro social insuficiente, no esoterismo charlatão, e no esteticismo esnobe. Mas Candido encontra-o, também, nas versões regionalistas do exotismo para francês ver, e do pitoresco para o leitor dos centros urbanos ufanar-se e/ou estarrecer-se.

Mais tarde, já nos anos de 1970, o ensaio "Literatura e subdesenvolvimento" reposiciona esse esquema de evolução dialética e positiva/construtiva, da história da literatura brasileira, elaborando-o em uma perspectiva que considera a façanha de escritores de literaturas de países colonizados, especialmente as hispano-americanas firmadas no cânone universal. Rosa havia morrido em 1967, sem Nobel, e embora já contasse com traduções nas línguas mais visíveis do cânone universal, não chegou a alcançar a repercussão de um Borges e de um García Márquez, talvez pelas dificuldades impostas aos tradutores, por seu uso de numerosas variantes dialetais do português brasileiro, ao lado de outros recursos de vocabulário com os quais Rosa monta sintaxes inventivas, em uma ficção carregada de humor e ironia, parodística. Era necessário posicioná-lo, na série da literatura latino-americana universal, inclusive para que a memória de sua contribuição não passasse desapercebida, na história do cânone universal.

Esse ensaio de Candido reposiciona e amplia o esquema de interpretação da história da literatura brasileira, fundado no Formação, e define a trajetória super-regionalista de 


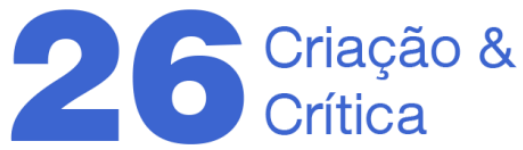

Rosa. Distribuído na obra de Candido e resumido no referido ensaio, esse esquema traça os pontos de evolução da literatura brasileira e culmina na transfiguração realizada por Rosa, a partir dos anos de 1940, daquilo que atravessa a literatura brasileira: a tensão dialética entre o artifício tosco do realismo documental e o artifício falseador do esteticismo míope. Transfigurados, esses artifícios de efeitos parciais tornam-se transcendentais, metáforas superiores (totalizadoras) dos sentidos de matérias sociais já formuladas, a partir de diversas abordagens das realidades brasileiras, por artistas e intelectuais. No final do "Literatura e subdesenvolvimento", Candido (2003, p.161-162) define a ficção de Rosa como: síntese super-regionalista dos dois principais segmentos da literatura brasileira. A excelência do ficcionista resultava do aproveitamento do melhor do regionalismo cujas fragilidades, 0 descritivismo e a cor local, Machado já havia apontado, bem antes de terem sido "sublimadas e como transfiguradas pelo realismo social", praticado no modernismo dos anos de 1930, em benefício da ampliação da pré-consciência do subdesenvolvimento. Entendo que, na expressão "como transfiguradas", Candido modula o tipo de transfiguração realizado na literatura de 1930, parecendo sugerir ter havido, naqueles anos, uma prévia da metamorfose do regionalismo, proporcional a tal estágio de pré-consciência do subdesenvolvimento. A transformação total e a consciência expandida, para além de si mesma, transcendental, vieram a acontecer depois, na literatura de Rosa, cujo realismo superior tem uma estatura tão universal como o de Machado, o que significa dizer que ambos realizaram obras pertinentes ao que há de humano, de sensível e de inteligível, em cada homem, em todo o mundo. Candido atribui a essas obras tal operação transfiguradora, empregando a categoria iluminista de Homem e pressupondo o pertencimento da literatura brasileira à Ocidental.

O ensaio atribui a Rosa uma estatura ímpar, equivalente à de Machado de Assis, e uma importante função de síntese. O escritor fundiu o melhor da tradição regionalista à contribuição modernista. Essa síntese pressupõe a explosão das tendências naturalistas, próprias ao período de consolidação das literaturas latino-americanas, o que ocorreu graças à transfiguração realizada por Rosa das matérias do regionalismo, uma tradição iniciada no nativismo, em uma situação política de dependência, por escritores pouco aptos a um tratamento humanizador de seus personagens. Como se sabe, a evolução do regionalismo teve origem no nativismo romântico; proliferou no processo do advento da República, a partir da onda realista-naturalista, e consolidou sua vinculação estreita à história da literatura brasileira; até começar a ser questionado, no marco zero modernista da pesquisa estética, da invenção verbal, por um projeto estético-político de invenção do nacional, que criou as condições para a receptividade do público ao romance de 30 , cujo sucesso se deu em um momento de condições superiores às sobredeterminações da literatura pelas tendências regionalistas e pelas modas estrangeiras. Assim resumi a evolução da história da literatura brasileira, cujos fundamentos Candido lançou no Formação, e nos demais textos que publicou, a partir dos anos de 1940. Naqueles anos quando, por assim dizer, iniciava sua 


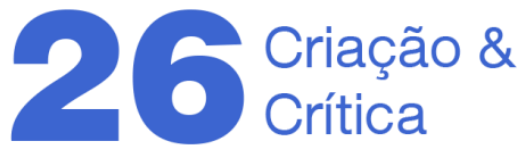

atuação como crítico, Candido deu um destaque enorme ao autor "estreante"7 de Sagarana [1946], em dois textos de crítica publicados em jornal, um de São Paulo e outro do Rio de Janeiro. Em crítica homônima ao título do livro, "Sagarana"8, o crítico louvava o "Dr. Guimarães Rosa" cuja obra nascia "universal pelo alcance e coesão da fatura" (CANDIDO, 1983, p. 245). Essa universalidade afetava a relação dos leitores com o problema do regionalismo e com o do nacionalismo, superando-os. Nessa resenha, Candido explicita aquilo que legou a Rosa, sua função de grande síntese dos dois principais segmentos da literatura brasileira: o exótico e o pitoresco do regionalismo associavam-se, em sua ficção, ao gracioso "movimento interior" (CANDIDO, 1983, p. 243-247), especialmente destacado naquela vertente do modernismo dos anos de 1930, que mais tarde veio a ficar conhecida como literatura intimista. Poucos dias antes, Rosa havia recebido outra crítica muito enaltecedora por parte de Candido ${ }^{9}$, que nela valorizava o autor de Sagarana, pela retomada do melhor do regionalismo do centro, já desgastado e tido como problema, em favor da construção de certo sabor regional, em uma "região da arte". Rosa havia transcendido a região geográfica, cujas matérias cozinhou com concentração, densidade, quase irreal (CANDIDO, 2002, p.185-186). Esses elogios monumentais, nos anos de 1940, tiveram grande repercussão, nessa época em que os escritores já procuravam se afastar do regionalismo, do nacionalismo, e se aproximar da arte universal. Sabemos ter causado certa polêmica essa estreia, tão bem sucedida, do autor de Sagarana, que estranhamente atingia o ambicionado universal, pela via do regional. Candido começava a apontar uma definição de regionalismo mais abrangente e arraigada, que a catalogação da literatura voltada para questões pertinentes ao mundo rural e/ou provinciano. Na América-Latina, também, essa taxonomia vinha se tornando bastante complexa.

Na conferência "A literatura e a formação do homem" [1972], Candido (2002, p.7792) informa haver se tornado uma tendência, na crítica latino-americana, decretar-se a "morte do regionalismo", cuja sobrevida, no entanto, associa à continuidade da situação de subdesenvolvimento, que mantém as culturas rústicas à margem da cultura urbana. Esse desejo de que o regionalismo morresse, para dar lugar a algo superior, já vinha de algumas décadas, remontando ao final dos anos de 1930. Nos anos de 1940, a transcendência aparece como efeito decisivo, na versão da transfiguração adotada por Candido; começa a aparecer também algo semelhante, na América Latina, na versão antropológica da transculturação, proposta por Fernando Ortiz que, algumas décadas depois, adquire grande destaque no $A$ cidade das letras [1985] do uruguaio Ángel Rama. Já nos últimos anos da

\footnotetext{
${ }^{7}$ Na década de 1930, Rosa já publicava contos em jornais de grande repercussão, e com significativo sucesso. Eles foram reunidos na antologia Antes das Primeiras estórias, de 2011.

${ }^{8}$ Refiro-me à crítica intitulada "Sagarana", que Candido publicou n'O Jornal do Rio de Janeiro, em 21/07/ 1946. O texto consta na fortuna crítica organizados por Eduardo Coutinho.

${ }^{9}$ Candido também publicou, naqueles dias, essa outra crítica sobre o livro, intitulada "Notas de crítica literária Sagarana", dessa vez no Diário de São Paulo, em 11/07/1946.
} 


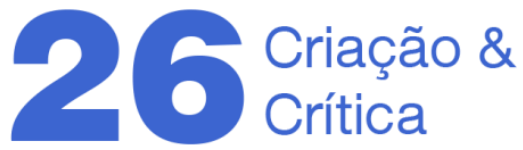

década de 1930, o desejo do universal vinha tomando conta dos escritores e dos críticos, a ponto de tornar predominante a dificuldade de atribuir valor estético aos particularismos do regionalismo, que muitos consideravam "morto", associando-o a um passado superado, atrasado, de base econômica rural, primária/pré-industrial, caudilhista, politicamente desarticulado, agitado por revoltas no campo e por demandas federalistas. Além dessa lista de problemas, o período também ficou conhecido por não oferecer autonomia nem à atividade intelectual, nem à produção cultural, por essa razão mesmo, provinciana. Era necessário representar apropriadamente as regiões com o fim de integrá-las; e, nessas representações unificadoras, as decisões estético-políticas miravam os universais.

\section{Romão: da afasia à enunciação do outro, mas lá...}

A necessidade de tornar as coisas e as regiões nacionais adequadamente representadas, na literatura brasileira, impulsionou um projeto político e estético, constituído na história da literatura romântica, iluminista, civilizacional. Ela privilegia os romances, separando-os em temas urbanos e rurais, e organizando-os em genealogias, segundo suas fases de evolução, rumo aos valores universais do Ocidente, fundado no Império Romano. Mesmo que a literatura universal não coincida com aquela voltada para questões urbanas, esse modelo evolutivo tem por horizonte valores civilizacionais materializados em certas cidades, ou pelo menos em lugares específicos delas. Desse modo, aprendemos a desvincular a linhagem do regionalismo, transfigurada por Rosa, e a do romance urbano universal de Machado, uma espécie de prévia à modernidade plena, uma transfiguração precoce de constrangimentos atrelados à história da formação. No entanto, prefiro considerar que tanto Machado como a onda regionalista, contemporânea a ele, participaram no conhecimento moderno, tal como se deu no país.

Quando o regionalismo proliferava, Machado publicou seu famoso ensaio "Instinto de Nacionalidade" [1873]. Candido considera esse momento decisivo, porque nele Machado realizou uma obra transfiguradora de matérias brutas, selecionadas e trabalhadas pelos românticos. Machado, ao mesmo tempo, identificava no ensaio defeitos de seu tempo, e passava a superá-los. Candido acatou a avaliação de Machado e concordou com ele quanto aos problemas daquilo que, durante o modernismo, veio a ficar conhecido como o regionalismo: o exotismo, o pitoresquismo, a suficiência nominal, a falta de profundidade psicológica, o lastro social incipiente. No final do século XIX, muitos escritores brasileiros compartilhavam o enorme entusiasmo mundial pelo romance realista, e os regionalismos proliferavam. Havia necessidade de continuar a demarcação do idioma próprio, o gigantesco português brasileiro, no país recém independente; e de assegurar que as diversas realidades do território nacional tivessem representação plausível, demarcadas em sua historicidade, cada uma delas laboriosamente elaborada nesse idioma. Havia um interesse mais ou menos 


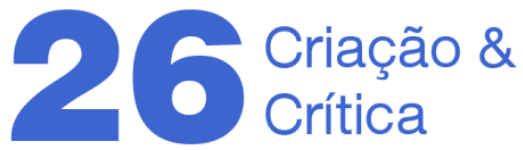

generalizado por gêneros "sérios", universais, como o romance realista e derivações do realismo, como o perspectivismo dos impressionistas. Machado escolheu outro caminho e talvez esse afastamento, do realismo a Eça de Queirós, ajude a entender que, embora obtivesse grande reconhecimento como escritor, também recebesse censuras de alguns de seus primeiros críticos, por supostamente ignorar a realidade do país. Na crônica "A nova geração" [1879], o escritor nega participação no entusiasmo pelo realismo dos romancistas contemporâneos a ele, por considerá-los afins a uma "poética do inventário" (ASSIS, 2019, parágrafo 3 e 40), uma postura coerente com a conformação jurídica de grupos letrados afins à exigência realista de transparência na transcrição fiel e detalhada das coisas, iconoclastas e, simultaneamente, satisfeitos com a ordem geral do universo, prontos a aplicar a teoria da seleção natural a uma triunfante celebração da seleção social, sem preocupação quanto à falta de justiça social.

A crise moderna da ficção aconteceu no romance, quando Machado publicou Memórias póstumas de Brás Cubas [1881] e Dom Casmurro [1899]. Anos antes, vinha manifestando algumas inquietações, como aquelas que encontramos no "Instinto de nacionalidade". Naquele ensaio, entre outras coisas, havia elogiado o regionalismo de Bernardo Guimarães, e mencionado a escassez de elaboração de caracteres, na literatura brasileira. Parecia ter em mente observações dessa natureza quando, nos anos seguintes, inventou a ficção de um autor defunto velhaco e desmemoriado, que se faz refratar em enunciados disparatados, supostamente produzidos pela memória falha de sua juventude ${ }^{10}$. O ensaio também manifesta apreço pela escrita de contos que Machado lamentava não se praticar muito em sua época, quando os escritores dedicavam-se mais aos romances e se comprometiam com a questão do nacional. Focando coisas miúdas sem inventariá-las, operando técnicas retóricas obscuras (da perspectiva dos grandes enunciados iluministas de definição da nacionalidade), nos anos seguintes, escreveu muitos contos, mais de duzentos, e também neles explorou caracteres, alegorias, e outras técnicas fundadas numa compreensão estoica do cômico, tal como na literatura do século XVIII de que gostava (Cf. PORTELA, 2013).

Entre os contos mais famosos de Machado, encontramos "Um homem célebre" [1883], publicado no periódico $A$ estação, e no livro Várias histórias [1896]. O conto trata de um compositor de polcas, que alcançou notoriedade nos novos tempos agitados da vida cultural, mundana, progressivamente laica, no Rio de Janeiro, em um Segundo Reinado já em crise, sob risco de descentralização política. Essa ficção alude a outro centro, o dos valores estéticos europeus assentados no historicismo, que apresenta a evolução da arte rumo sua realização moderna. O protagonista frustrava-se cada vez que se via bloqueado, ao buscar inspiração em sua galeria de mestres, que incluía tanto Cimarosa, compositor da

\footnotetext{
${ }^{10}$ A respeito das técnicas retóricas usadas por Machado para inventar a ficção de memória encenada na narração de Brás Cubas e na de Bento Santiago, Cf. "Dom casmurro: simulacro \& alegoria" (HANSEN, 2008, p.143-177).
} 


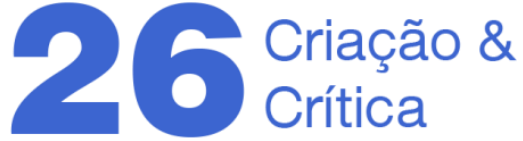

famosa ópera cômica O matrimônio secreto, como outros compositores de corte clássico que antecipavam certo pendor romântico, como Mozart, Beethoven e Chopin. Outros contos modernos de Machado recolocaram o dilema de músicos que, por sofrerem certo descompasso de si mesmos em relação a seu tempo, buscavam algum tipo de identificação a mestres europeus. Mas a imprecisão dessa tentativa frustrada só os fazia reincidir em um duradouro, arraigado e incompreendido bloqueio criativo, pelo menos, no que diz respeito aos gêneros canônicos. Naquele mesmo periódico, e no mesmo ano, Machado publicou "Cantiga de esponsais" [1883], e logo depois o incluiu no Histórias sem data [1884]. A julgar pelo título, essa publicação não trata de questões datadas, e essa sugestão se reforça por uma nota de "Advertência", na qual Machado assinala o estranho fato de quase todos os contos terem seus acontecimentos atrelados a datas específicas, neles informadas. Tendo por fundo o impacto de valores modernos, na efervescente vida musical do Rio de Janeiro que, no Segundo Reinado e na República, vivia enormes avanços em relação aos tempos anteriores. Esses contos compartilham o tema da melancolia sentida por músicos que, embora celebrados pelo gosto popular, intimamente sofriam bloqueios criativos, provocados pela inoperância de padrões valorativos alheios, europeus. Ambos os contos foram publicados, depois de Memórias póstumas de Brás Cubas [1881] e, embora o sistema literário distintivo da modernidade, para Candido, ainda não estivesse consolidado, esses contos documentam o ponto de vista de Machado sobre coisas modernas fundamentais, como a atenção à historicidade dos sujeitos, e em particular a historicidade dos mitos de autor constituídos em convívio com a noção romântica, prevalecente na imaginação pública, do gênio original, originário, e deslocado.

"Cantiga de esponsais" narra coisas determinantes na melancolia do velho mestre Romão, atrelada ao fato de ter amargado um bloqueio criativo durante sua vida adulta, das duas últimas décadas do século XVIII até 1813. O último impulso do velho Romão, abatido e moribundo, foi retomar a cantiga esponsalícia que havia abandonado após a morte prematura de sua jovem mulher, em 1781. Sua esperança era a consagração dessa cantiga que, segundo sonhava, se realizaria no futuro, lá pelos anos de 1880 , e por ironia de Machado, esse prognóstico de Romão, quanto a um gênero típico do catolicismo lusitano, destoava daquele fim de século XIX, quando tendências iluministas, humanísticas e classicistas, favoreciam a laicização da vida musical (Cf. ARAUJO, 1963). Naquele fim de século, a composição de Romão teria tido mais sucesso de público, caso fosse uma polca, ou um maxixe, porém a coisa mais alegre na casa dele havia sido seu cravo e, nessa trilha sacra, acabou se destinando à sombra do cânone universal, como o protagonista de "Um homem célebre". Morador de uma casa modesta, nua e sombria, na rua da Mãe dos homens, o velho Romão vivia como músico pobre, de quem o preto velho Pai José era a verdadeira mãe. Havia passado sua vida adulta, durante a transferência da capital do Vice-Reino para o Rio de Janeiro, sob a aura civilizatória do período pombalino, e aqueles haviam sido seus anos de fama, na corte joanina. Mas o leitor já o encontra velho, quando Romão adoece 


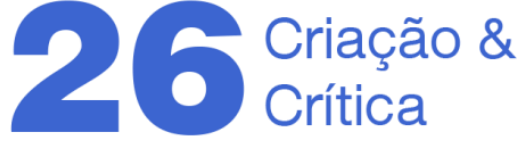

gravemente, e o conto narra o momento em que decide não manter relegada ao futuro a composição de alguma coisa própria. Enquanto isso, habitava o lugar simbólico da mãe, afetivo e exterior à memória pública, às genealogias do cânone universal. Recebia os cuidados de seu escravo Pai José, e mantinha sua permanente crise criativa. Assim, Machado representava aquele século, quando a coexistência de valores modernos, e escravagistas, gerava uma espécie de afasia ${ }^{11}$, em artistas melancólicos como Romão. Em vista do cânone universal, a consagração do próprio estava fora de alcance. Só o humor de Machado para contornar a melancolia de seus músicos.

A situação do bloqueio criativo de Romão alegoriza a questão estética e política da invenção contínua do próprio, na história da literatura brasileira, oferecendo representações que hipertrofiam significações presas na língua e sugerem, por não ditos, os limites da subjetividade do músico. Romão aspirava realizar-se como compositor de algo próprio. "Não exigia uma peça profundamente original, mas enfim alguma cousa, que não fosse de outro e se ligasse ao pensamento começado." (ASSIS, 1884, p.55) A única causa da melancolia de Romão era não poder compor, "não possuir o meio de traduzir o que sentia" (ASSIS, 1884, p.53), embora fosse célebre naquela época, evocada pelo narrador como algo inimaginável nos anos de 1880, naqueles tempos idos das missas cantadas, no início do século. Quando o conto começa, o narrador aponta o velho Romão regendo uma missa na Igreja do Carmo, espaço de grande destaque na vida musical e política do Rio de Janeiro, onde peças litúrgicas ornaram os rituais de sagração da memória dos eminentes da corte joanina, seus batismos, casamentos, e missas do sétimo dia. Durante os breves anos de seu casamento, celebrado em 1779, que o deixou viúvo pouco depois, havia tentado acabar ao menos o próprio canto esponsalício, mas juntou apenas umas poucas notas. Romão encontrou pouca inspiração para construir memória, embora amasse reger missas.

$\mathrm{Na}$ última parte do conto, quando se encontra velho e moribundo, em 1813, tenta ativar a memória dos tempos de casado e retomar a composição, pensando que um dia, várias décadas depois, em 1880, alguém poderia tocá-la e lembrar do mestre Romão. Com essa esperança, rematou seu princípio "em um certo lá; este lá, que lhe caía bem no lugar" (ASSIS, 1884, p.54). Sem avançar além disso, apesar de saber música "como gente" (ASSIS, 1884, p.55), acabou ativando a inspiração em outra pessoa. No final, pouco antes de morrer, escuta a vizinha recém-casada cantarolar inconscientemente uma linda frase musical, inédita, e principiada em um certo lá. Enquanto tentava compor em seu cravo, na Rua da Mãe dos Homens, escutou esse lá, que poderia designar o lugar vizinho, onde assiste seu esforço de enunciação ter uma breve e linda ressonância na voz do outro. Com humor, Machado faz Romão tomar parte, ainda que efêmera, destinada a um futuro incerto,

${ }^{11}$ Ao nomear esse protagonista, Machado de Assis citava o conto medieval cristão, segundo o qual houve o milagre de São Romão de Cesaréia, na Síria do início do século IV, que superou a mudez quando passou a falar sem língua, depois de a terem cortado por pregar a pagãos. 


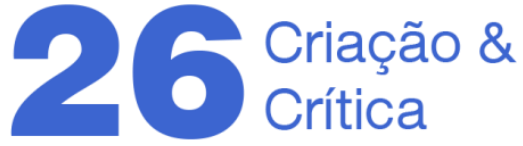

na forma eternal de uma cantiga esponsalícia, sem registro escrito; conduz o leitor até o ápice de sua estranha realização, como compositor desse princípio de cantiga comunitária, como (co)autor de fragmento anônimo. "O mestre ouviu-a com tristeza, abanou a cabeça, e à noite expirou." (ASSIS, 1884, p.56) Pesaroso, deixou na memória, incerta e futura, do outro esse princípio, esse lá que talvez (penso isso assumindo a impertinência de torcer pelo personagem, de final triste) prenunciasse Gonçalves Dias em 1843... O legado de Romão, duradouro e arraigado como uma sina, cujos limites históricos Machado sublinha, é esse lá... Parece-me que o lá de Romão ressoa também no "Lá, nas campinas", outra estória de Tutaméia. Mas agora, estudo a invenção de reminiscências do sapateiro Romão, no "Reminisção". Nele, ao modo humoroso de Machado, Rosa alegoriza e contorna a historicidade da jornada civilizacional encarnada em Romão, já em outra fase de transfiguração: a do regional-universal.

\section{O realismo regional-universal do pós-guerra encontrando seus limites}

No final da década de 1930, houve uma polêmica nos jornais envolvendo Mário de Andrade, Graciliano Ramos e dois escritores, que publicavam no periódico Dom Casmurro, Jorge Amado e Joel Silveira (Cf. SALLA, 2006). Cito-a apenas para dizer que essa polêmica indicava uma tensão, compartilhada pelos rapazes do periódico Dom Casmurro, quanto a Mário de Andrade. Atribuíram a ele um esteticismo esnobe, de escritor isolado em uma torre de marfim, diletante e, naquela época, muito aquém do entusiástico Paulicéia desvairada [1922], admirado por muitos dos escritores de 1930. Nessa polêmica, destaco a intervenção de Graciliano Ramos, que publicou, em 1939, a crônica "Os sapateiros da literatura", que encontramos republicada no póstumo Linhas tortas [1962]. Nessa crônica, Graciliano Ramos reafirmava sua conhecida fixação com a escrita e se colocava ao lado dos rapazes do Dom Casmurro, escritores migrantes, que escreviam levando em conta o pagamento, operando como sapateiros, com suas pequenas facas, armas insignificantes, embora cortem. (Graciliano ponderava a metáfora monetária, que Mário de Andrade havia usado, de modo polêmico, tendo soado esnobe, quando também se alfinetava com Jorge Amado. Mário de Andrade distinguia-se do escritor bahiano, ao defender a própria atenção a detalhes formais, mesmo em um momento de ebulição política, e disse considerar as sutilezas do estilo valorosos tostões, que reunidos também formam riqueza, como os cheques de cinquenta contos.) Numa carta enviada a seu tio Vicente Guimarães em 1947, Rosa aludiu à participação de Graciliano Ramos nessa polêmica e afirmou sua afinidade com a posição dele. Nos termos de Rosa, Graciliano dedicava-se ao artifício, ao cuidado com as operações da escrita, em atenção à materialidade e à historicidade de seus efeitos. Rosa ainda atribuiu a Graciliano dedicação ao artifício, distinguindo-o da intenção artificial que, descuidada quanto à opacidade das matérias 


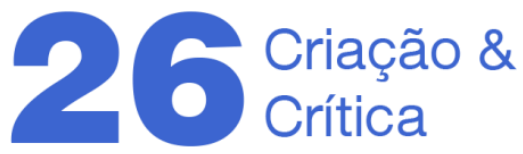

manipuladas, pretende comunicar um conteúdo político transparente e bem-intencionado. Nessa carta, Rosa declara estar ao lado de Graciliano, em seu combate.

Agora, porém, a hora é de combate, de ofensiva. Tudo está mudando, seo Vicente. Não retornaremos ao verbalismo inflacionado e oco de Coelho Neto (...). Não se trata de um movimento intencional, artificialmente concebido. É, apenas, a voz dos tempos. (...) "Arte é artifício", brada Graciliano Ramos. (GUIMARÃES, 2006, p.134)

O interessante nessa afinidade quanto ao combate, assim considerado, é que tal definição de artifício se constrói em um campo semântico atravessado pelo valor da materialidade da escrita $^{12}$, passando ao lado do campo semântico do regional-universal, assediado por valores metafísicos em pauta, no final da década de 1930. O empenho de fazer a história evoluir em um rumo utópico, civilizacional, por adequação a valores etnocêntricos, por vezes dividiu espaço com a tradicional ânsia de superação instantânea, ou de eliminação urgente, de um passado desagradável, associado ao mal gosto, a ser superado por concepções universalistas de arte.

Quando começava a escrever o Formação [1959], a partir de 1945, Candido louvou a estreia de Rosa com Sagarana [1946], por recuperar os melhores aspectos clássicos e humanistas do regionalismo. Rosa ocupa, na história da literatura brasileira, um lugar de destaque, e Candido teve participação, das mais importantes, na canonização de seu nome de autor, por muitos conhecido como um romancista do pós-guerra. Acontece que esses critérios, fundados nos anos de 1940, dão maior destaque a seu romance e dificultam a leitura de publicações posteriores, como o Primeiras estórias [1962] e o Tutaméia [1967]. O livrinho vermelho, da José Olympio, já começa, nos índices, contrariando qualquer expectativa a respeito de um autor do pós-guerra, aquele que apura a forma até torná-la orgânica ao corpo social, monumental quanto à interpretação da história, e transcendental por oferecer, no estilo, operações acessíveis, tanto à inteligência, quanto à sensibilidade do homem culto. Submetendo a disposição a esses encantos, trazidos no bojo da noção de organicidade, à prova de fogo do humor, Tutaméia já começa parodiando a noção de forma orgânica, no índice de leitura, e apresenta quarenta finais "felizes"/de superação, destoando daquele que era um período político dos mais tensos. $O$ índice sugere um exercício ininterrupto de leitura de fragmentos, a serem combinados e recombinados, prometendo iluminação, pela via desse esforço paciente. Passando longe da monumentalidade de Grande sertão: veredas [1956], os quarenta contos de Tutaméia são bastante curtos, além

\footnotetext{
${ }^{12}$ Mônica Gama (2014) estuda a materialidade de um volumoso arquivo de fragmentos, que Rosa acumulava e organizava em listas, durante a preparação minuciosa e, em geral, lenta de seus livros. Especialmente no caso de Tutaméia, Gama (2014, p.19-20) assinala o fato do título desse livro ter sido citado por Rosa, no posfácio do volumoso Sezão [1937], manuscrito inscrito por ele sem sucesso, sob o pseudônimo Viator, em um famoso concurso literário, e que quase uma década depois resultou em Sagarana, depois do ficcionista ter seguido certas sugestões do jurado Graciliano Ramos.
} 


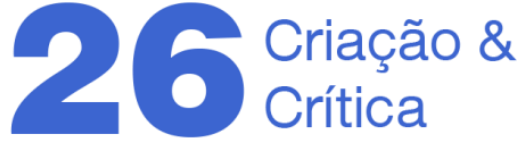

do próprio título aludir a valores ínfimos, tutaméias, tostões ${ }^{13}$. Outra coisa que pode ter oferecido dificuldade aos leitores, quando afinados ao "encanto" meio mítico, que consagrou a literatura latino-americana do pós-guerra, é o tipo de transcendência estética oferecido por Tutaméia. Em vez de sugerir qualquer coisa plena de sentido, o livro insiste muito no equívoco, no atrito de discursos armados com técnicas narrativas extraídas de formas comunitárias cômicas (chistes, adivinhas, provérbios, etc.), então consideradas prototípicas $^{14}$, conforme o famoso estudo de Huizinga, no seu Homo Ludens [1938]. Vale ressaltar que a publicação de Tutaméia, em 1967, encontrou uma imaginação pública assombrada pela desordem, na ditadura. Vermelho, o livro recusava qualquer efeito de transparência, ou de clareza cotidiana, e parodiava critérios valorativos do pós-guerra, que haviam consagrado o autor.

O cânone ocidental, as obras clássicas que o constituem, comunica valores humanistas, em alta na década de 1940 (e em crise na de 1970), universalmente apreensíveis para qualquer homem capaz de refazer o sentido racional e sensível de suas operações, quando formado na tradição Ocidental. A crença nessa possibilidade de comunicação ampla entre os homens, das diversas nações do Ocidente, ainda não soava muito polêmica na produção intelectual brasileira, mas nas décadas seguintes, com os processos mundiais de descolonização, alguns começaram a adotar a perspectiva dos povos dominados, colonizados, pelos valores do Ocidente. Quando nos anos de 1970, Candido vinculou as limitações da literatura brasileira ao subdesenvolvimento do país, considerando sua história colonial, destacava a obra de Rosa como uma exceção, um modelo de transcendência estética e política. Candido passou a adotar a perspectiva do subdesenvolvimento, mantendo sua participação nos valores do humanismo ocidental, que o formaram. No entanto, a crítica ao etnocentrismo dos valores clássicos, representados pelo homem do humanismo do século XIX, tornava-se uma questão central para outros intelectuais também ativos naquele momento, nos anos de 1970, como se confere na crise moderna do sujeito, estudada no pós-estruturalismo francês, na virada antropológica, e no culturalismo. A literatura brasileira produzida nesse período, o das polêmicas internacionais e nacionais quanto à crise moderna do sujeito, alimentou-se de questões afins a esse debate e

\footnotetext{
${ }^{13}$ A dissertação de Bernardes de Andrade (2004) analisa paratextos das edições de Tutaméia, pela José Olympio, como a ilustração de uma moeda, cujas faces trazem emblemas, um de coruja (dracma grego antigo) e o outro de cunho pessoal do escritor (o do seu signo, de câncer), que se alternam ao final de alguns contos. A metáfora da história ocidental (dracma grego) alterna-se com a do mito do autor (do signo de câncer), sublinhando um jogo de projeções mútuas, nas mobilizações desses valores.

${ }^{14}$ No ensaio "A literatura e a formação do homem", Candido (2002, p.80-81) também emprega essa diferenciação de formas mais humildes (a anedota, a adivinha, o trocadilho, etc.), formas já mais complexas (mitos, cantos folclóricos, lendas) e as formas impressas, que correspondem a nosso ciclo de civilização, entre as quais a literatura é uma das modalidades mais ricas, por seu poder humanizador.
} 


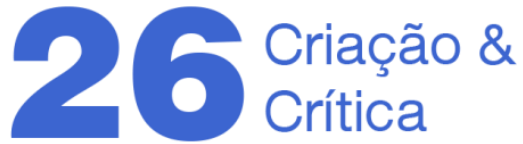

ficou conhecida como uma literatura desencantada, aquela posterior à perda de encantos regionais, representados tanto na literatura brasileira da transfiguração, como na literatura latino-americana da transculturação. Quanto ao conto "Reminisção", a cena da transfiguração daquela mulher feia oferece uma paródia do que há de canônico, de hagiográfico, nessa sublimação de encantos "mortos", nessa metafísica da superação estética do passado de atraso.

\section{Sapateiro sempre sabe: transfigurar coisas brutas}

O conto "Reminisção" é protagonizado pelo sapateiro Romão, e conta de seu amor pela mulher com quem namorou, casou e viveu até "morrer", ou fingir morrer. A primeira parte narra a vida do casal, em um povoado que, desde o início do namoro, não simpatiza com a moça, considerando-a feia, e deduzindo disso sua maldade. Na segunda parte, a situação complica-se quando ela trai o marido com um forasteiro, e passa de muito magra a muito gorda, além de adoecer gravemente, o que confirma as suspeitas do povo a respeito do mal que aquela mulher podia atrair, e isso estava na cara. Na terceira parte, o marido adoece de uma moléstia simples, mas graças aos cuidados dela, piora cada vez mais. Nos parágrafos finais, o moribundo Romão sorri nos braços de sua amada, que chora e se ilumina, transfigurando-se naquilo que o rosto dela será no futuro, belíssimo, enquanto 0 marido morre, ou finge morrer.

Como se vê, o anedótico é dos mais simples e, embora tenha um final estranho demais para ser fabuloso, assemelha-se, pelo humor pitoresco, a contos curtos, como os clássicos do primeiro Tchékhov, publicados em jornal popular barato ${ }^{15}$. Parece-me que é de contos como aqueles mais populares, montados analiticamente com caracteres, que Machado disse sentir falta na literatura brasileira, no "Instinto de nacionalidade", embora a crítica geralmente entenda tratar-se de um desejo de ampliação da complexidade psicológica

\footnotetext{
${ }^{15}$ Vale lembrar que não foram esses contos pinturescos que canonizaram Tchékhov, mas outros, mais longos e publicados em revistas sofisticadas, caras, com personagens psicologicamente complexos. No geral, os personagens de Rosa têm nomes muito significativos; e no Tutaméia, o autor os inventa mais ou menos como Tchekhov, em seus primeiros contos, cujos tipos recebiam nomes descritivos - o Sr. Caloteiro (Moshénnikov), por exemplo - conforme técnica clássica aplicada nas antigas sagas russas, e em contos pré-cristãos, que oferecem quadros alegóricos para comunicar valores comunitários. Como se sabe, com o avançar do século XIX, a ficção moderna passou a recusar esse tipo de técnica e seu pressuposto: o fundamento metafísico dos gêneros e da ordenação clássica das coisas, das classes; recusando a sacralidade dos valores clássicos, passava a confrontar seus substitutos, que iam de discursos científicos a discursos evolucionistas da espiritualidade, cujos valores consideramos pseudocientíficos hoje, sem muita polêmica. As operações modernas de canonização trocaram seus pressupostos religiosos por outros, em geral, mais ou menos científicos.
} 


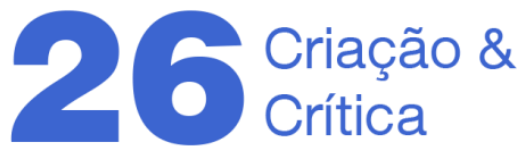

de cada personagem, de cada character ${ }^{16}$. Já na segunda metade do século XIX, tornou-se comum considerar a sofisticação de um autor proporcional ao grau de complexidade psicológica de seus personagens, no que os romances levam vantagem, em relação a gêneros mais breves. Além do anedótico simples e pitoresco, "Reminisção" também não exibe personagens psicologicamente complexos, muito pelo contrário. Em vez de uma coleção de defeitos regionalistas, o conto usa essas coisas com humor, aproveitando suas ressonâncias, numa representação alegórica e parodística.

Assim como a literatura moderna, no século XIX e no XX, demonstrou estilos de amor às coisas tal como são (amor fatı), o narrador de "Reminisção" também trata com estranha deferência, contrapondo-a ao estarrecimento do povo, a estória do sapateiro Romão e de seu amor inabalável, fatal, por Drá, depois chamada Pintaxa, e futuramente Nhemaria. Moderno na atração por anônimos multitudinários, esse conto brevíssimo representa um episódio extraordinário e longo, duradouro, na memória de Cunhãberá: a estória de vida e morte de um homem, que amou demonstrando um estilo inaceitável de juízo, antes do final estabelecer sua superioridade.

Romão amava. Decerto ela também, se sabe hoje, segundo a luz de todos e as sombras individuais. (...)

Disso ninguém dava razão: o atamento, o fusco de sua tanta cegueira? Sapateiro sempre sabe. Ou num fundo guardasse memória pré-antiquíssima. Tudo vem a outro tempo. (ROSA, 1979, p.82)

A anedota, como se vê, é das mais simples: ele amava a toda prova, e ninguém entendia o motivo. Tanta devoção a uma coisa tão feia era apenas cegueira dele, ou a reminiscência de uma memória perdida, extemporânea à tradição humanística, clássica e iluminista? Tratava-se da invenção afetiva e solitária de uma reminiscência?

\section{A alegoria parodística, em três partes, e o ponto de vista de Rosa}

O que torna "Reminisção" um conto meio velhaco, a princípio, é o vocabulário exótico, os regionalismos e os neologismos. Depois, o leitor precisará de uma atenção zen, e de uma disciplina estoica, para desfrutar a técnica de sua retórica analítica, que recorta caracteres de proveniências diversas, e os combina em uma representação alegórica, além de parodística.

\footnotetext{
${ }^{16}$ Parece-me que a valorização privilegiada de personagens psicologicamente complexos também pode contribuir, mesmo a contragosto de seus agentes progressistas, em processos modernos de disciplinamento social, de normalização de comportamentos, de tipificação de sujeitos, e na hierarquização dos valores do colonizador, que dão distinção a alguns, civilizados e cultos, excluindo os demais, brutos.
} 


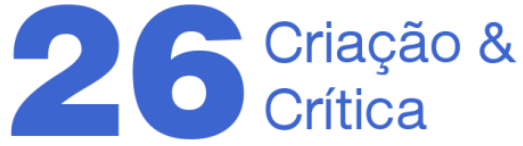

O conto "Reminisção" faz uma paródia do regionalismo, representando-a em três partes. Seus dois momentos de transição correspondem a dois fenômenos de transfiguração, que avultam no processo de evolução da história da literatura brasileira. No marco da transição do primeiro momento para o segundo, temos a perspectiva amorosa do sapateiro Romão e alguns desafios que geram o conflito. Esse momento faz a paródia da fase romântica, e de sua crise, remetendo ao período em que o transfigurador Machado de Assis publicou "Cantiga de esponsais", o conto sobre o músico Romão. Em seguida, o conto "Reminisção" transita para a terceira parte, a final, quando a situação conflituosa parece expirar com a "morte" do sapateiro Romão, que faz a paródia da função transfiguradora de Rosa. Essas paródias formam três quadros, três pinturas vivas com função alegórica, tal como tableaux vivants das fases evolutivas da história dos regionalismos. Esquematicamente, fica assim:

1 - O nome do protagonista do conto "Reminisção", homônimo ao do "Cantiga de esponsais" [1883], alude ao momento em que o conto de Machado foi escrito, quando a nova geração do realismo entrava em crise quanto ao romantismo, o regionalismo proliferava, e Machado de Assis fazia sua intervenção transfiguradora. A primeira parte do conto corresponde à aproximação romântica e naturalista da realidade em estado bruto, durante o namoro inicial desse regionalismo com o outro cultural, elaborado de modo pinturesco e exótico. O período aludido é parodiado em "Reminisção" que, na parte inicial, narra o namoro de Romão, quando se dá o constrangimento público, quanto ao aspecto "feio" do objeto de seu amor.

2. Na segunda parte, o conto narra a situação de conflito amoroso, que escandaliza o povo, enquanto Romão a supera com generosidade extraordinária. Essa parte faz a paródia daquele momento de crise do romantismo, quando houve denúncias do "feio", como as que se realizaram no então prolífero realismo à Eça de Queirós, e em suas versões regionalistas. O contraste muito marcado entre o feio-mal-regressivo e o bonitobom-justo, também presente no gótico a que o conto alude, oferece uma caricatura do etnocentrismo, cujas premissas vão atritando até a indeterminação do sentido do conto.

3. No final, temos a "morte" do sapateiro Romão e a transfiguração, que canoniza o objeto de seu amor. A continuidade do estranho romance parece ameaçada pela "morte" ambivalente de Romão, e a feiura doentia da coisa amada transfigura-se, ilumina-se. Sabemos que aconteceu a transfiguração, predominantemente assimilada pela crítica de Rosa, e da qual os leitores, em geral, têm notícia, mas conforme Candido, o regionalismo continuará objeto do amor fati dos escritores de literatura brasileira, enquanto persistirem as condições de subdesenvolvimento. O conto conclui a paródia da "morte" do regionalismo, ou de sua transfiguração, no realismo regional-universal do pós-guerra.

Ao pensar a função de Rosa, na história da literatura brasileira, considero a contribuição de Candido, que foi decisiva. Pode-se dizer que um é o pai do outro, mutuamente. Rosa é o autor do regional-universal, que participa do fenômeno latino-americano da floração 
super-regionalista, e Candido é o autor da história da literatura brasileira, do Formação, que fundou as premissas críticas da canonização desse ficcionista. Depois, textos e resenhas de Candido, posteriores a "Sagarana", posicionaram Rosa no ápice da evolução dessa história: a segunda transfiguração (em obra de realização total) das constrições estético-políticas ao regionalismo. Interpreto "Reminisção" como uma alegoria parodística, em três partes, da história do regionalismo, e de seu "fim" transfigurado. Parece-me que, nesse conto, e em alguns outros de Tutaméia, Rosa avalia a função de seu nome de autor.

Antes de passar à minha análise de "Reminisção", explico a razão pela qual me parece que, nesse conto, Rosa lança estranhas balizas, parodísticas, em torno do funcionamento de seu nome de autor, na história da literatura brasileira. O índice de leitura de Tutaméia desenha, para o leitor, a identificação de alguns contos ao nome de João Guimarães Rosa. O índice tem seus títulos organizados em ordem alfabética, de $A$ ("Aletria e hermenêutica") a $Z$ ("Zingaresca"), e alguns contos a interrompem. Quando reparamos nos títulos dos contos fora de ordem, descobrimos neles uma outra ordem, a das iniciais do nome do autor, os caracteres J.G.R. Então, o nome desse autor participa em uma ordem de coisas, interferindo nela. Como o índice identifica o nome de João Guimarães Rosa a alguns contos, correlaciono cada um deles ao ponto de vista do autor sobre determinada coisa. "Reminisção" parece-me alegorizar uma ordem de coisas análogas, na chave do humor, à história do regionalismo, amplamente conhecida como uma tendência iniciada no romantismo, e destinada a sua transfiguração, a sua superação estética total, em Rosa. Ainda há outras pequenas desordens, em torno das iniciais J.G.R., mas não as analisarei agora, quando considero apenas o sentido da interrupção da ordem alfabética, efetuada pela letra "R" de Rosa, de "Reminisção" e de Romão.

"Reminisção" avalia as matérias que usa, os caracteres a que me referi, unidades literárias e não literárias (científicas, espiritualistas), nesse conto posicionado, no livro, como enunciação do ponto de vista de Rosa, identificado a Romão, o amante inveterado de uma megera de rudez exemplar. Como se nota pelo índice do livro, "Reminisção" é um dos contos que ocupam o lugar da intervenção das iniciais do nome de João Guimarães Rosa, na ordem alfabética, enciclopédica, parodiada no livro: quer dizer, a ordem iluminista, do progresso, da civilização mecânica e industrial, que repercutiu nos discursos positivistas, deterministas, evolucionistas, dos fins do Império. Qual a intervenção de João Guimarães Rosa? Como Romão, Rosa é o ponto em que algo, o regionalismo, morre ou finge morrer, enquanto 0 efeito dessa morte transfigura o objeto de seu amor. De acordo com a função do nome de Rosa, na história da literatura brasileira, o que "morria" sem morrer era o regionalismo. Mas, em outra direção, podemos considerar que a morte, em questão, dizia respeito à crise moderna do sujeito e da ficção, já experimentada por Machado de Assis e encenada por ele em "Cantiga de esponsais"; crise que retornava como questão, notavelmente a partir de 1968, nas polêmicas do estruturalismo francês com o humanismo ocidental, e com os fundamentos iluministas das ciências. 


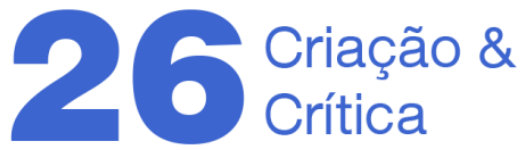

Rosa sabia que era universal, ou seja, o autor a transfigurar as constrições estéticopolíticas da história da literatura brasileira, depois de Machado de Assis. Muitos o distinguiram por sua superioridade ao regionalismo que, via de regra, era dado por morto, já nos anos de 1940. A superioridade dessa transfiguração foi atribuída por Candido à transcendência integradora, diplomática quanto ao fundamental no pós-guerra, e possível graças à disciplina clássica, humanística. Na história da literatura brasileira, Rosa ocupa o lugar da "morte" do regionalismo, de sua transfiguração. Dá continuidade ao regional, que, no entanto, humaniza pela eliminação do que há de tosco, de indefinido, nas matérias brutas do regionalismo: coisas como o pitoresco, o exotismo, o excesso de vocabulário regional, e os personagens sem complexidade psicológica.

\section{A situação de quadros pinturescos e o vocabulário exótico}

Anteriormente, expliquei o modo como entendo as três partes da alegoria, pois, segundo me parece, essas três pinturas vivas apontam para fora, descontínuas, e parodísticas de coisas diversas. Agora, passemos ao exercício de aproximação do vocabulário exótico, e a atritos de retóricas, a que isso induz. "Reminisção" narra a estória de amor de Drá e Romão. O sapateiro Romão mantém amor incondicional por uma mulher progressivamente difamada, que no final, enquanto antecipa a morte dele, estranhamente se transfigura, superando seu estado de megera, e assumindo uma nova forma luminosa, diante de todos. Mas esse milagre paradoxal, de beatificação no mariticídio, pela graça do deus ex machina, só acontece no desfecho. No começo do conto, o narrador observador informa do estarrecimento do povo, pelo casamento de um homem remediado, como o sapateiro Romão, com essa mulher horrorosa cujo nome, a princípio, é Drá, destacada por uma feiura tida como sintoma, pinta, índice de maldade.

Os primeiros parágrafos, do conto, resumem os termos em que os leitores poderão especular sobre o sentido da estória, sua moral, o valor comum veiculado nela.

VAI-SE falar da vida de um homem; de cuja morte, portanto. Romão esposo de Nhemaria, mais propriamente a Drá, dita também a Pintaxa - ímpar o par, uma e outro de extraordem. Escolheram-se, no Cunhãberá, destinado lugar, onde o mal universal cochila e dá o céu um azul do qual emergir a Virgem. (...) Divulgue-se a Drá: cor de folha seca escura, estafermiça, abexigada, feia feito fritura queimada, ximbé-ximbeva; primeiro sinisga de magra, depois gorda de odre, sempre própria a figura do feio fora-da-lei. Medonha e má: não enganava pela cara. (ROSA, 1979, p.81)

Esse conto curto passeia pela história da literatura, aludindo a estilos de contar do século XIX, rumo ao canônico Rosa. O estilo sentencioso da narração, a função sumária dos 


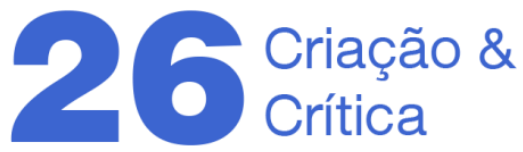

parágrafos iniciais, e a diagramação do incipit, escrito em caixa alta, remetem à produção crescente de compilações escritas de contos orais, no século XVIII, quando a época dos Impérios passava por um processo de transição para a dos Estados Nacionais Europeus, modernos. Além disso, o nome do protagonista também cita o do conto "Cantiga de esponsais", que tem por fundo o processo de transição do Rio antigo (o das missas cantadas) para o dos maxixes, quando a cidade tornou-se moderna, a seu modo. Depois, quando o conto passa à segunda parte, e a evidência da falta de juízo daquele amor de Romão agrava-se, o narrador usa uma expressão, que evoca o estilo do gótico colonial, muito apreciado por contistas regionalistas, dos fins do II Império e da Primeira República ${ }^{17}$. A terceira parte do conto, a final, encena a transfiguração do baixo ao elevado, o que alegoriza a função do próprio Rosa, na história da literatura brasileira: proporcionar, ao leitor, a experiência de uma forma moderna, inventada como reminiscência, que ilumina coisas embrutecidas, e dadas por mortas, superadas, nos discursos de modernização, coisas como aquelas das quais vinham tratando os regionalismos.

Em alguns de seus textos, Candido (2002, p.88) destaca Rosa, por um novo tipo de elaboração da língua, mais empático aos personagens rudes, do que os estilos regionalistas. Falo, por exemplo, do ensaio "A literatura e a formação do homem" [1972]. Rosa superou um tipo regionalista de separação desumanizadora: o distanciamento da criatura rude, por parte do criador civilizado, cuja perspectiva coincide com a do narrador observador culto. Essa superação retomava o sentido empático da representação da fala do outro cultural, anteriormente bem equacionada por Simões Lopes Neto, cuja ficção também dissolve "de certo modo o homem culto no homem rústico" (CANDIDO, 2002, p.91). Esse "dissolvendo de certo modo" se parece ao ideal harmonizador da mestiçagem, que também transfigura as raças da formação em raças novas, melhor adaptadas ao ambiente, e civilizadas. Candido aposta no esforço de construir empatia, por meio de princípios mínimos comuns, como a língua coloquial, normalizada por escritores cultos, que não exageram no uso de regionalismos, nem adotam notações fonéticas caricatas, ao escreverem a fala do outro cultural. Por isso, não simpatiza com o abuso de vocabulário regional, que the parece pitoresco e exotista ${ }^{18}$. Em "Reminisção", parece-me que Rosa não economiza muito nos regionalismos, nem tampouco oferece um glossário ${ }^{19}$, embora em Tutaméia haja dois

${ }^{17}$ Do cânone universal, não participam estilos de entretenimento como o gótico colonial, nem como a polca e o maxixe. Confiram o gótico, em Bernardo Guimarães, Coelho Neto, Afonso Arinos, Simões L. Neto, e Bernardo Élis.

${ }^{18}$ A respeito da atitude etnográfica, adotada pelo narrador protagonista, no conto "Uns índios, sua fala", e sobre a identificação dele a seu autor, recomendo o ensaio de Vélez Escallón (2018), intitulado “'Zero nada, zero': uns índios Guimarães Rosa, sua fala”.

${ }^{19}$ O recurso do glossário era usado em edições de obras regionalistas, como a de 1949, que consagrou nacionalmente o Contos gauchescos, publicado pela primeira vez, por Simões Lopes Neto, em 1912, com êxito regional. A julgar pelo sucesso tardio desse livro, os anos de 1940 foram 


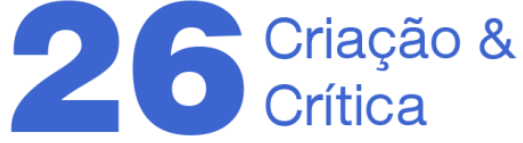

glossários parodísticos. Quando fazemos uma leitura corrida de "Reminisção", pela primeira vez, entendemos perfeitamente a anedota, que é simples, embora estranha, também graças ao vocabulário exótico. Acontece que, quando me aproximo um pouco mais desse vocabulário, a anedota torna-se mais interessante, e as avaliações, que vinha fazendo dela, acabam se indeterminando, se dissolvendo. Como se esse conto exótico terminasse me exotizando, quer dizer, vou ficando com uma sensação estranha, a respeito da facilidade com que vinha assimilando a razoabilidade de Cunhãberá. Depois de algumas idas ao dicionário, percebo-a etnocêntrica e racista.

A primeira peripécia de "Reminisção", na transição para a segunda parte, se dá quando a situação inicial do casamento complica-se, pois Drá comete uma traição conjugal descabida, aos olhos do povo, com um forasteiro. Mas, para o pasmo de todos, o marido a perdoa facilmente. Ao explicar a perspectiva escandalizada do povoado, o narrador observador aproxima-se dela, e a enuncia com humor, usando um lugar comum das ficções góticas. O povo já adivinhava, desde o início, pela cara, pela pinta, a maldade daquela mulher infiel, doentia, e "feia como os trovões da montanha" (ROSA, 1979, p.82). Já era feia na situação inicial, e se torna horrível na segunda parte, mas agora com trovoada. Repito a citação, com glosas rápidas, entre chaves, de regionalismos, apelidos, neologismos e palavras pouco cotidianas.

VAI-SE falar da vida de um homem; de cuja morte, portanto. Romão esposo de Nhemaria [Nomeada-Maria], mais propriamente a Drá [Dragão], dita também a Pintaxa [a Pintosa, a Sintomática] - ímpar o par, uma e outro de extraordem. Escolheram-se, no Cunhãberá [Mulher-do-caboclo], destinado lugar, onde o mal universal cochila e dá o céu um azul do qual emergir a Virgem. (...)

Divulgue-se a Drá: cor de folha seca escura, estafermiça [mal arrumada, estorvo], abexigada [com erisipela/abissínia], feia feito fritura queimada, ximbé-ximbeva [nariz chato]; primeiro sinisga [sinistra + vesga] de magra, depois gorda de odre [gorda de bêbada], sempre própria a figura do feio forada-lei. Medonha e má: não enganava pela cara. (ROSA, 1979, p.81) [chaves minhas]

A mulher era invariavelmente feia e desagradável, mas, no final, o povo de Cunhãberá a renomeia Nhemaria, quando a canoniza. O substantivo guarani "nhe-ẽ" significa, ao mesmo tempo, o fundamento da pessoa guarani ou seu espírito-nome, conforme Ara Rete (2015, p.1113), e linguagem/nome conforme o Dicionário guarani-português (TIBIRIÇÁ, 1989, p.123).

Acrescento, ainda, outra descrição de Drá, que aparece na situação inicial. "Todo tempo o atanazava, demais de cenhosa, caveirosa, dele, aquela mulher mandibular." (ROSA,

mais favoráveis, que os anteriores, à consagração nacional desse escritor, de posição destacada, na linhagem de Rosa. 


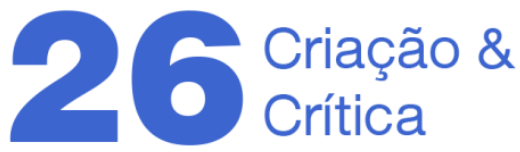

1979, p.82) Esse diagnóstico, traçado pelo povoado, já no parágrafo introdutório, parodia discursos do determinismo de Spencer e de Darwin. Também, da criminologia de Lombroso, cientista que acabou convertendo-se ao espiritismo, passando a incluir esses fenômenos em seus estudos. Lombroso investigava a essência de criminosos natos, a partir do tamanho da mandíbula. Quando o conto passa à segunda parte, Drá mostra-se reativa no trato com as pessoas, ao que se segue a esterilidade do casal, o agravo logo perdoado da infidelidade, os problemas graves de saúde, superados por ela graças aos cuidados de Romão, e a moléstia leve dele, que o tratamento dado por ela conduziu ao leito de morte. Tudo isso resulta na beatificação dela.

Que final poderia ter uma situação tão horrorosa? Em se tratando de Tutaméia, não há erro, todo final tem algo de feliz, ou de superação. O que pode incomodar, pois afeta um estranho otimismo fora de hora, em 1967, e se inscreve, pela via do amor fati, na literatura moderna. Esses contos postulam quarenta modos de justiça poética, e recusam a paixão jurídica pela duplicação da ordem, identificada por Machado, na crônica "A nova geração" [1879]. No caso de "Reminisção", a solução inadvertida, desse quadro de horror, fica ao encargo do deus ex machina, que resolve tudo com o milagre do branqueamento por aflato, efeito colateral da erisipela. A mulher Drá(gão), durante todo o conto, padeceu, de pedra na mão, uma progressiva feiura de partir espelho. No final, ante o marido já moribundo, subitamente torna-se esperançada, enquanto transfigura-se na luminosa, alva, belíssima, futura Nhemaria. Drá, a conhecida Pintaxa, acaba integrada a Cunhãberá, depois de branqueada e cristianizada, ainda que por doença, tornando-se a branca e bela Nhemaria ${ }^{20}$.

Com a estória de Drá e Romão, Rosa também apresenta uma paródia da teoria platônica das reminiscências, e indetermina, com muito humor, o conceito de "transfiguração" de matérias brutas em formas orgânicas. Talvez porque destacava essas operações, que construíram a canonização do Rosa super-regionalista, Tutaméia não agradou muito. Porque teria exagerado no humor, dando as costas à sociedade pós-64 e pré-68. Pode ter parecido displicente, quanto ao irracionalismo saliente nesse período de crise profunda. Conclusões assim podem pressupor o esquema de canonização do super-regionalismo, que o livro parodia. Deixo a questão: o que significa transfigurar uma Drá(gão), um monstro, em um objeto de culto, na alva, belíssima, futura Nhemaria? Parece-me que essa estória tem ressonâncias na passagem de uma estética refém do atraso, o regionalismo, para outra superior a ele, o super-regionalismo. Parodiando a passagem do feio-mau ao bonito-virtuoso,

${ }^{20}$ Anita Martins Rodrigues de Moraes (2018) publicou um artigo, que considera o argumento de Clastres a propósito de como a cultura etnocidária dos colonizadores correlaciona-se à ética humanista de integração do outro, do indígena, para os benefícios da civilização. A partir dessa ponderação, Moraes (2018, p.45-47) mapeia leituras que Candido fez de Engels e de antropólogos funcionalistas, afins a postulados evolucionistas retomados em afirmações do crítico sobre a evolução ambígua da sociedade da técnica. Conferir o artigo de Moraes, "A função da literatura nos trópicos: notas sobre as premissas evolucionistas de Antonio Candido". 


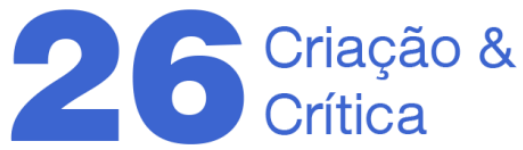

o conto também destaca a historicidade dessa metafísica da superação. Suponho que contornar o roteiro internacional do irracionalismo dos povos americanos, dos subdesenvolvidos, da necessidade de tutela de uma razão ordenadora vertical, pode ajudar a pensar realidades, cujos aspectos danosos assombram a imaginação do futuro. O conto de Rosa, naquele que também era um momento de crise, apostava na exposição dos materiais usados na escrita, arremetendo-os uns contra os outros, criando situações embaraçosas e paradoxais. Usa o próprio idioma nacional, tratando-o como a ficção de uma língua comum, pentecostal. Rosa aproveita 0 efeito exótico do vocabulário regionalista, às vezes indistinguível de alguns de seus neologismos, para exibir a seu leitor a Babel do idioma português brasileiro. Como se sabe, a unificação da língua, mais ou menos comum aos falantes nacionais, se deu por imposição do Marquês de Pombal, seguida da proibição, por decreto em 1758, de línguas faladas pelos habitantes da colônia. A "reminisção" dessas línguas lampeja, nas numerosas variantes regionalistas do idioma nacional, aproveitadas no conto de Rosa.

\section{Soltando as línguas, faladas antes de Babel, na língua}

O ensaio "A literatura e a formação do homem" [1972], de Candido (2002, p.77-92), defende o caráter humanizador da literatura, definindo-a como fenômeno de civilização. Defende a superação do regionalismo, por Rosa, pelo requinte que dispensou a temas regionais. Requinte, geralmente, aplicado apenas a temas urbanos. Antes de Rosa, Simões Lopes Neto havia oferecido, ao leitor civilizado, uma espécie de "comunidade do meio expressivo", de participação em uma humanidade, em cuja esfera se nivela ao rústico, e essa experiência proporciona a ele uma visão da realidade à qual pertence (CANDIDO, 2002, p.87 e 92). O conto "Reminisção" encena, de um estranho modo, essa oferta de uma espécie de comunidade, na literatura transfiguradora de Rosa, onde os participantes se humanizam, e o civilizado se nivela ao rústico, o que resulta em uma nova visão, reveladora, da realidade. Como se sabe, no pensamento modernista, de modo geral, a integração das raças da formação, entre si, era tida como uma condição, fundamental, para o enraizamento da cultura nacional, e para se fundar uma civilização, no país.

Rosa torna essa estranha integração um tema, e o sentido da técnica narrativa, usada no conto "Reminisção". Podemos achar desconcertante, ou divertido, o humor dessa mudança instantânea, dessa transição imediata, de um período prolongado de repulsa generalizada, a uma súbita reverência despertada em todos, no final daquela estória de amor. Em todo caso, precisamos ponderar que o povoado, apesar de suas enormes reservas, quanto ao objeto do amor de Romão, mantinha relações amistosas com o caboclo. O conto começa informando o leitor sobre o fato do povo ter guardado na memória, por um longo tempo, essa estranha estória de amor, e de horror. Assim, sugere que Cunhãberá traz, 


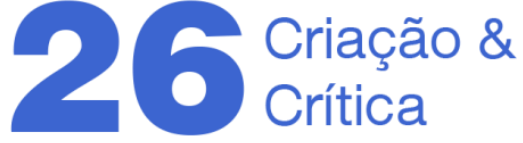

em seu nome, uma referência a essa estória, tratando-a como um possível mito fundador do povoado. O neologismo acopla o substantivo tupi "cunhã" (mulher do caboclo) e o verbo "berá" (brilhar) da Língua Geral Brasílica (Cf. OLIVEIRA, 1936, p.133 apud LEITE, 2013, p.101). Cunhãberá guardou na memória aquele momento em que a mulher do caboclo se pôs a brilhar, tornando-se a alva e linda Nhemaria. E esse povo encarna a própria imagem de uma civilidade, fundamentada nos saberes das ciências positivas, do século XIX. Quer dizer, Cunhãberá não metaforiza o outro da civilização, mas se funde aos rudes da roça $e$ aos da província, encenando discursos que, no século XIX, constituíam o civilizado.

Parece-me que a reverência ao estranho objeto de culto, Nhemaria, no final da estória, destaca distâncias imensas, e as contorna. A namorada dragão, Drá, também conhecida, logo depois, como a esposa infiel e doente Pintaxa, no final é integrada, após um estranho fenômeno de branqueamento, quando assume a forma da canonizada Nhemaria. Em "Reminisção", os diálogos são curtíssimos, e o estilo da fala do narrador (culto, clássico, onisciente) traça estratégias retóricas, que tornam Cunhãberá ainda mais estranha, e cômica, que Drá. O estilo dessa fala mantém seu deslocamento, em relação à chamada língua cotidiana, coloquial, aquela comungada nas normatividades de alguns grupos sociais, em regiões centrais. Os grupos letrados onde se encontram os leitores de Rosa não falam assim, tampouco as populações do campo e arredores, nas mais diversas regiões que forneceram material a Rosa como vocabulário, dados culturais, e a condição de objetos das representações regionais. Candido apreciava o tratamento, que Rosa dava à língua, por considerá-lo integrador; não se tratava de uma língua regionalista, nem nacionalista, mas universal, inclusive com contribuições internacionais (estrangeirismos) e com invenção vocabular (neologismos). O conto "Reminisção" parodia a avaliação desse aspecto integrador, que o toma como um projeto humanizador, no que diz respeito aos grupos de falantes previstos na representação. Digamos que a paródia mostra um processo de integração mais ruidoso, talvez desconcertante, e com humor situa-o na história da literatura brasileira.

Talvez o mais intratável, nesses tipos de traços pinturescos, quase tão imóveis e lentos como pinturas vivas, dentro de um quadro de costumes provincianos, pintado em tintas góticas, seja não representarem unidades psicológicas, que contenham uma crítica clara às tipologias dos grupos sociais, pressupostos na representação. Falo do povo do sertão, que o conto constitui como objeto de uma representação metamórfica, e dos leitores a quem o narrador clássico onisciente reporta-se, tratando-os como ouvintes de uma comunidade extemporânea. Rosa inventou esses personagens, agrupando neles os caracteres heteróclitos de sua ficção, que confronta matérias de outras ficções, e de discursos não mais filiados aos gêneros de ficção, como os científicos e os religiosos, ambos discursos literários, no século XIX. "Reminisção" equaciona coisas e paixões diversas. Mais diretamente, alude ao conto "Cantiga de esponsais", de Machado, que coloca como tema a 


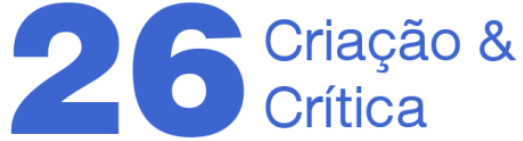

questão da falta de uma língua própria, da afasia associada à experiência do artista moderno, em um país de história colonial.

O romance realista foi um gênero útil à tarefa épica da nova geração, dos anos de 1880, que tomou a seu encargo produzir uma literatura própria, representativa da realidade nacional, retomando a missão romântica de escrever, no idioma português brasileiro. A avaliação que Machado fez daquele período, no ensaio "Instinto de nacionalidade", forneceu algumas premissas a estudos de Candido, decisivos na consagração de Rosa: os regionalistas incorreram, muitas vezes, em um nacionalismo superficial, implícito no abuso da cor local, do pitoresco, e do exótico. O crítico ainda atribuía essa superficialidade à pouca consciência, e à fraca empatia dos escritores regionalistas pelos homens rudes, parecendo apostar na construção gradativa da integração dos rudes aos civilizados.

No ensaio "O homem dos avessos", Candido chamou a atenção para o fato do ficcionista ter superado a tendência da literatura brasileira a um tipo de realismo, que se detém no documento bruto, com dificuldade de oferecer aproximação, superação da distância, transcendência. E no ensaio "Esquema de Machado de Assis", Candido assinala que, até Bastide sustentar o contrário nos anos 40 , críticos vinham afirmando que a realidade do país escapava a Machado, como se ele falhasse ao cumprir a tarefa colocada pelo realismo. Candido defendeu a superioridade do realismo de Machado, e a de Rosa. Pareceme que esses ficcionistas apostaram na crise moderna, acerca desses padrões realistas, destacando sua materialidade, sua opacidade, e a historicidade de seus usos. Naquele fim do século XIX, padrões de representação não realistas também foram usados, por escritores do realismo regionalista, por vezes, com o cuidado de assinalarem a adequação das enunciações e das perspectivas, submetidas à tutela do discurso civilizacional, esclarecido, da narração culta. Representações não realistas (maravilhosas, míticas, esotéricas) serviram algumas vezes, aos escritores regionalistas, como molduras construídas em abismo para encaixar a perspectiva, ou mesmo a fala, do outro cultural, o rude, dentro de um marco maior, realista, sustentado pelo narrador observador culto. Formas prototípicas, como as do conto maravilhoso, as dos milagres, adéquam-se à representação da fala e da perspectiva de personagens primitivos e rudes. Formas assim também estão repostas, na literatura gótica, e filtradas, segundo a fundamentação científica da literatura espiritualista, que obteve sucesso entre os novos leitores do período Republicano, quando se iniciou a expansão da alfabetização, da leitura, do livro. Muitos, no século XX, procuraram transcendência, de modos diversos. Conforme o Caos e cosmos [1976], estudo que Suzi Sperber fez da biblioteca de Rosa, o autor tinha certa predileção por riscar e anotar seus livros de temas espirituais. Rosa alimentou a imagem de homem religioso, em algumas declarações, e muitos de seus leitores apreciam sua literatura, nessa chave. A história brasileira da leitura vai ao encontro dessa imagem canônica de Rosa que, além de homem religioso, assumiu a função de romancista de um realismo superior; nos termos de Candido, super-regionalista. Em Tutaméia, Santo Inácio, São Ladislau, São João, São Gedeão, São Romão, nomeiam os 


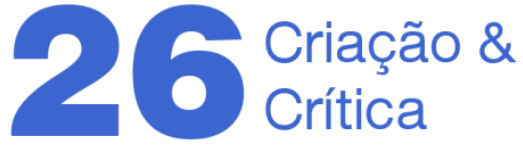

protagonistas dos contos, que alegorizam o ponto de vista de João Guimarães Rosa sobre a materialidade da ordem do discurso, na qual interveio como autor.

Tutaméia foi lançado no pós-guerra, quando fortes embates ideológicos evocavam algum sentido para a história da humanidade, enquanto alguns consideravam as contribuições do não senso, do absurdo, e questionavam a eficácia de uma razão ordenadora, vertical. As operações de canonização, dedicadas a Rosa, ativam toda uma semântica metafísica: transfiguração, transcendência, superação, universalidade, obra total. Rosa tornou-se célebre por realizar um tipo de realismo regional, que põe do avesso, e transfigura, em outra coisa totalmente superior, a tradição regionalista. A transfiguração apresenta outro modo da figura, que pode ser seu avesso, seu exato negativo, versões orgânicas da sociedade, naquele momento histórico; e Candido tinha por método definir o princípio mínimo comum de estruturação dessas unidades correspondentes. Mas, e quando Rosa apresenta um conto como "Reminisção", salientando o caráter artificioso, remendado e conflituoso, de sua ficção, que reposiciona a reminiscência de uma experiência moderna, como a do Romão de Machado, em que o princípio comum fundamental, da língua própria, é uma Babel de línguas extintas, e emergentes na língua do colonizador?

Se a dominante, na história da literatura brasileira, é o realismo, e se ele seria seu destino, algumas ficções de Rosa talvez se tornem embaraçosas, também, quando enfatizam artifícios muito salientes, como os da alegoria feita por Machado na década de 1880. Como Romão, no "Cantiga de esponsais", Rosa confronta as dificuldades de inventar uma língua própria, e comum, o que resulta em uma língua artificiosa, resultante da conjunção de diversos tempos e espaços, quando associa regionalismos de diversas partes, neologismos, estrangeirismos. Parodiando a reminiscência de matérias, orgânicas à cultura e aos povos que a formaram, Rosa destaca, em "Reminisção", a materialidade, a historicidade, de palavras e de discursos, em conflito na sua biblioteca. Por isso, nos custa encontrar o lugar de um conto, como "Reminisção", e de um livro como Tutaméia, na obra do autor transfigurador, ou modernizador do regionalismo. Mais ainda, custa situar esses textos, na história da literatura brasileira, do modo como estão armadas suas genealogias. Essa dificuldade, de situar "Reminisção", resulta do fato do conto atritar com premissas dessa história, ao enfatizar os próprios artifícios, requisitando a apreciação deles, pelos leitores, produzindo equívocos, associações afetivas de matérias, com históricos conflitivos. A seu leitor, Rosa oferece pequenos insights, que o soltam um pouco da goma elástica da dita língua cotidiana, do realismo, também muito sovada nos meios de comunicação massivos. Oferece também humor, em deslocamentos de padrões canônicos.

\section{Referências}

ANDRADE, A. M. B. de. A velhacaria nos paratextos de Tutaméia: terceiras estórias. 2004. (Dissertação de Mestrado, Teoria e História Literária). Campinas: UNICAMP, 2004. 


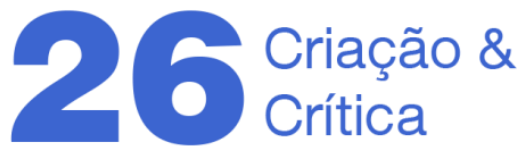

ARA RETE, S. B. Nhe'ẽ, reko porã rã: nhemboea oexakarẽ. Fundamento da pessoa guarani, nosso bem-estar futuro (educação tradicional): o olhar distorcido da escola. 2015. (Trabalho de Conclusão de Curso da Licenciatura Intercultural Indígena do Sul da Mata Atlântica). Florianópolis: UFSC, 2015.

ARAUJO, M. de. A modinha e o lundu no século XVIII. São Paulo: Ricordi, 1963.

ASSIS, M. de. "A nova geração". Machadiana Eletrônica, Edição e notas por Gracinéa I.

Oliveira e José Américo Miranda, Vitória, v. 2, n. 4, p. s-s, jul.-dez. 2019.

.O Primo Basílio. Obras completas de Machado de Assis (v.6). São Paulo: Formar, s./d., p.164-172.

.Cantiga de esponsais". In:

Histórias sem data. Rio de Janeiro: Garnier, 1884, p.49-56.

CANDIDO, A. "Literatura e subdesenvolvimento". In:

A educação pela noite e outros ensaios. São Paulo: Ática, 2003, p. 140-162.

. "A literatura e a formação do homem". In: . Textos de intervenção. São Paulo:

Duas Cidades/Ed. 34, 2002, p.77-92.

"Notas de crítica literária - Sagarana". In:__. Textos de Intervenção. São Paulo:

Duas Cidades, 2002, p.183-189.

"Um instrumento de descoberta e interpretação". In: Formação da literatura brasileira: momentos decisivos (v.2). Belo Horizonte-Rio de Janeiro: Itatiaia, 2000, p.97-105. . "O homem dos avessos". In: COUTINHO, Eduardo (Org.). Guimarães Rosa. Rio de Janeiro: Civilização Brasileira, 1983, p.294-309. (Fortuna Crítica. V.6).

"Sagarana". In: COUTINHO, Eduardo (Org.). Guimarães Rosa. Brasília: Instituto Nacional do Livro; Rio de Janeiro: Civilização Brasileira, 1983, p.243-247. (Fortuna Crítica. V.6).

COVIZZI, L. M. Prefácios travestidos: estudo sobre as funções dos prefácios de Tutaméia: Terceiras Estórias. In: . O insólito em Guimarães Rosa e Borges. São Paulo: Ática, 1978, p. 88-102.

GAMA, M. "Classificar-criar: o breviário criativo de Guimarães Rosa".Manuscrítica, n.26, p.10-26, 2014.

GUIMARÃES, V. Joãozito: a infância de Guimarães Rosa. São Paulo: Panda books, 2006.

HANSEN, J A. "Dom Casmurro: simulacro \& alegoria". In: GUIDIN, M. L. et al. (Orgs.). Machado de Assis: ensaios da crítica comtemporânea. São Paulo: Editora UNESP, NLM, 2008, p.143-177.

.O O. A ficção da literatura em Grande sertão: veredas. Hedra: São Paulo, 2000.

LEITE, F. R. A língua geral paulista e o Vocabulário elementar da língua geral brasílica. 2013. (Dissertação de Mestrado, Linguística). Campinas: UNICAMP, 2013.

MORAES, A. M. R. de. "A função da literatura nos trópicos: notas sobre as premissas evolucionistas de Antonio Candido", Revista Cerrado, v.26, n.45,p.41-54, 2018. 


\section{Criação \&}

Para além das palavras: representação e realidade em Antonio Candido. São Paulo:

UNESP, 2015.

NOVIS, V. Tutaméia: engenho e arte. São Paulo: Perspectiva, 1989.

OLIVEIRA, J. J. M. de. "Vocabulário Elementar da Língua Geral Brasílica". Revista do Arquivo Municipal, São Paulo, v. 25, jul. de 1936, p.129-174.

PORTELA, D. S. "Machado de Assis e a tradição dos comediantes estóicos". Machado de Assis em linha, Fundação Casa de Rui Barbosa, Rio de Janeiro, v.6, n.12, dez. de 2013, p.138-153.

REGO, J. E. de S. O calundu e a panaceia: Machado de Assis, a sátira menipeia e a tradição luciânica. Rio de Janeiro: Forense Universitária, 1989.

ROSA, J. G. Tutaméia: terceiras estórias. Rio de Janeiro: José Olympio, 1979.

TIBIRIÇÁ, L. C. Dicionário guarani-português. São Paulo: Traço, 1989.

VÉLEZ ESCALLÓN, B. O. "'Zero nada, zero': uns índios Guimarães Rosa, sua fala”.Alea, Rio de Janeiro, vol. 20-2, p. 53-73, mai/ago de2018.

Recebido em: 21/09/2019 Aceito em: 31/10/2019

Referência eletrônica: CAIXETA, Maryllu de Oliveira. A transfiguração do dragão ou a sobrevida do regionalismo. Criação \& Crítica, n. 26, p., jun. 2020. Disponível em: $<$ http://revistas.usp.br/criacaoecritica $>$. Acesso em: dd mmm. aaaa. 